Anna Majewska, Krzysztof A. Worobiec, Edyta Bugowska

\title{
Locality in the era of globalization \\ Carriers of the memory of historical landscapes - studies on the Evangelical cemeteries of the Masuria region (Poland)
}

\begin{abstract}
The main purpose of this article was to present contemporary narratives (social and scientific discourse) about the Evangelical cemeteries of Masuria, based on the examples of the activities under two projects, whose common denominator are the restoration of memory and the protection of cultural heritage. The present elaboration concerns selected issues of the functioning of the tangible cultural heritage in the Masuria region (in Pasym and one of the deserted villages). This piece of writing also describes how the spaces of Protestant cemeteries can be interpreted anew, especially as a result of documentative works.
\end{abstract}

Keywords: cultural heritage, history, documentation, interdisciplinary research projects, Protestantism, East Prussia, local communities.

Oh yes, you would have to visit this old cemetery. Cemeteries say a lot about the past. Whoever wants to learn something about history, must start with cemeteries...

\section{Introduction}

"The fate of cemeteries overlaps with the fate of people. When people leave, their cemeteries die too", wrote Wiktor Knercer, an expert on the Masurian landscape (2003: 160). But, because of their materiality, cemeteries can 'store' information about the lives of former local communities for a long time to come. In the words of Krystyna Dąbrowska-Budziło (2011: 229), they have a distinct genius loci - "they are endowed with content so deep that even repurposing or destruction of their form cannot erase it". Even if cultural continuity is maintained, many historical burial sites are a valuable source of knowledge about the life of past generations, and sometimes 'speak' about that part of history which has been blurred in the living discourse of memory. Thus, cemeteries are kind of repositories

\footnotetext{
${ }^{1}$ A. Surminski (2008: 39).
} 
of history (carriers of memory - Kula 2002). Functioning in a changing cultural landscape, they constitute a link between the past and the present. They are sites anchored both 'there' and 'here and now'.

The main purpose of this article is to present contemporary narratives (social and scientific discourse) about the Evangelical cemeteries of Masuria, based on the examples of the activities under two projects, whose common denominator are the restoration of memory and the protection of cultural heritage. The present elaboration concerns selected issues of the functioning of the tangible cultural heritage in the Masuria region:

- the area of the old Evangelical cemetery in Pasym (under the project entitled: Evidently important: documentation of the cemetery and the chapel in Pasym); - the area of the Evangelical cemetery in Wilki (a deserted village) (under the project entitled: Lost Villages of the Pisz Forest (Fig. 1).

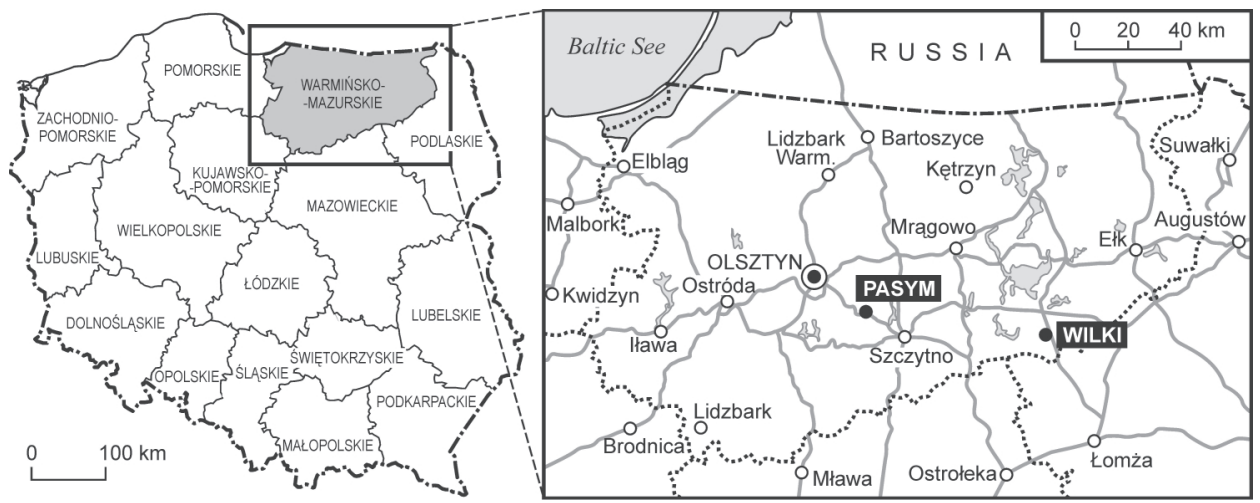

Fig. 1. Localization of cemeteries discussed in the case studies

Source: own elaboration.

This piece of writing also describes how the spaces of Protestant cemeteries can be interpreted anew, especially as a result of documentative works. Focus on individual elements of the geographical environment (in this case the components of the on-the-ground structure of cemeteries, as well as microhistorical analyses) shows how, in the age of globalization, people turn towards what is regional and local, towards the so-called 'small homelands' of the present and former rural communities of Masuria, and - several dozen decades ago - East Prussia.

Research into the Evangelical cemeteries of Masuria, conducted to date, has defined two main trends that significantly differ in terms of their research optics, including the selection and interpretation of information about Protestant cemetery planning schemes and their functioning in the geographical environment: 
- a humanist trend that includes: basic documentary research into individual elements of a cemetery planning scheme (spatial layout, grave markings, epitaphs), specialized analyses (e.g. in the field of landscape architecture, thanatourism, epigraphy);

- a natural trend that includes: documenting, and narrow-specialization analyzing (e.g. phytosociological, dendrological, pedological analyses carried out within the areas of the cemetery planning schemes).

The pioneer in documentative works on the Evangelical cemeteries of Masuria was the Provincial Heritage Monuments Protection Office, which in the 1970s initiated their methodical inventory-taking ${ }^{2}$. Another turning point came in the early 90s when, after the political transformations, people started making appeals for saving seriously devastated and neglected cemeteries (Jasiński 1993). A conference organized in 1992 by the Polish Historical Society, the Wojciech Kętrzyński Centre for Scientific Research, and the Commission for the Preservation of Monuments at the Polish Tourist and Sightseeing Society in Olsztyn, led to establishing the Social Committee for Saving the Old Cemeteries in Warmia and Masuria (Jamiołkowska 1993: 241). It undertook a number of activities aimed at popularizing the idea of cleaning up cemeteries and raising awareness of the need to protect them as well as spreading knowledge on them (including scientific conferences and publications). However, it focused its activities on the western part of the present-day province, while the eastern and southern parts were omitted.

Nevertheless, the subject of the Masurian cemeteries has been becoming more and more popular since the 1990s, gaining a place among the issues of protection of cultural heritage sites as well as within the currently developing research trend concerning transformations that happen in the cultural landscapes of contemporary Poland. Among others, at the University of Warmia and Masuria in Olsztyn, students began writing papers on individual sites ${ }^{3}$.

Issues concerning the Masurian cemeteries are presented by monographic publications, including co-authored publications (vide e.g.: Żurkowska 2008, Nekropolie Warmii... 2016). A number of smaller contributory works have been created too (inter alia: Bielawny 2006; Bitowt 1999; Knercer 2003; Kudrzycki 2009; Majewska 2016). Morever, studies appeared concerning elements of cemetery planning schemes, considered, among other things, as sources in research into local history (vide e.g. Mazurowska 2009). In turn, the research program concerning the Masurian Evangelical cemeteries, carried out by the

${ }^{2}$ It resulted in, inter alia, the publication of a list of sites in 1984 by the Office of the Provincial Conservator of Monuments (Jasiński 2003).

${ }^{3}$ As mentioned by J. Chłosta (2011: 730), at least 21 master's theses were written that constituted monographs on cemeteries (they concerned, among others, sites located in: Świętajno, Mikołajki, Szczytno, Giżycko, Dźwierzuty, and Korsze). 
Warsaw University of Life Sciences, was focused on geospatial issues, including landscape architecture and the geography of tourism (thanatourism ${ }^{4}$ ) (vide inter alia: Długozima et al. 2013, 2015 $)$.

An important branch is constituted by research into the natural environment of cemeteries - mainly vegetation (inter alia: Majgier 2012; Majgier, Rahmonov 2013; Żurkowska 1999, 2000), but narrow-specialization analyses in the fields of dendrology (Ploszaj-Witkowska, Leoniak 2010) and pedology (Majgier 2010; Majgier, Rahmonov 2012) ${ }^{6}$ are being conducted too.

The projects that have been discussed in this work stand out significantly from other activities performed for the cultural heritage of Masuria, in particular the sepulchral heritage. They bring a new formula to activities aimed at its protection, among others, to the activities that integrate documentative works with social activities (voluntary and community). This means inclusion - into the current regional identity - of sites which, after the interruption of cultural continuity in the territory of former East Prussia, have become forgotten or unwanted heritage and for many years remained in the margins of social interest.

\section{Case studies}

\section{Old Evangelical cemetery in Pasym}

Project: Evidently important: documentation of the cemetery and the chapel in Pasym

\section{Organizer's perspective}

Pasym is the oldest town of Southern Masuria ${ }^{7}$. In this small village there is an active, historical Evangelical church. This religious building is one of the best-preserved pieces of architecture in all of Masuria. Today, it is being maintained by a small Protestant community of Pasym. In Pasym, there is also a place that, despite being a historical memory carrier located almost in the city center, seems to be abandoned and somewhat forgotten. It is an old Evangelical cemetery. Perhaps, this is because the last burials were conducted there in the late $19^{\text {th }}$ century.

\footnotetext{
${ }^{4}$ Thanatourism - a term introduced by A.V. Seaton (1996) which, most generally speaking, means "tourism to places that document and commemorate death" (Tanaś 2006: 85).

${ }^{5}$ In this work, 67 Evangelical cemeteries in the Maskulińskie and Pisz Forest Districts were valorized.

${ }^{6}$ Some smaller studies, which have not been discussed due to the volumetric constraints of the text, are listed in the bibliography of the history of culture and cultural heritage of Warmia and Masuria for the years 1990-2009 elaborated by I. Lewandowska and A. Romulewicz (2010).

${ }^{7}$ The settlement unit acquired town privileges in 1386 (Orłowicz 1991: 144).
} 
The cemetery gates were closed for the last time then. This was due to the fact that, on the outskirts of the village, the community organized a new cemetery, where burials have been taking place to this day (Knercer 2006: 721). The old Evangelical cemetery has existed since at least the first half of the $18^{\text {th }}$ century, as evidenced by the archival plan from 1750 on which it is marked (Knercer et al. 2013: 6). On a slight elevation in the northern part of the cemetery planning scheme, surrounded by old trees (over 70 years old), there is a prominent burial chapel, built in 1856 (Pestka 2013: 3; Knercer et al. 2013: 57). It is severely devastated, with, among other things, numerous defects in the plasterwork and brickwork, as well as an almost entirely collapsed internal flooring (the crypt is filled with rubble) (vide Chlebowicz, Strużyński 1995; Pawłowska 2013; Pestka 2013: 6). According to A. Letkiewicz, the history of the building is connected with a family tragedy: the wife and two children of the head of the local post office were poisoned to death by mushrooms. This was why he built the chapel in the cemetery, where the embalmed bodies of the family were buried (Letkiewicz 2006: 18-19). However, the text of the foundation plaque located on the southern facade of the building only mentions the two spouses ${ }^{8}$. The cemetery itself - which still has a partially legible spatial layout, gravestones, and partially preserved historical vegetation (among others, the trees planted along the main avenue) - constitutes, as emphasized by W. Knercer, "an autonomous, clearly spatially accentuated mass, which is a dominant feature in the landscape of the city" (Knercer 2008). Still, this cultural heritage site is subject to continuous destruction.

The cemetery has been the subject of the documentary research and workshops under the project entitled "Evidently important: documentation of the cemetery and the chapel in Pasym" organized by the Jantar Association and a partner - the "Światowid" Center for European Meetings in Elbląg (financed by the National Heritage Institute), with the support of the Provincial Heritage Monuments Protection Office in Olsztyn, the City and Commune Hall in Pasym, institutions of Pasym - the Municipal Cultural Center, the Municipal Public Library, the Elementary School in Pasym, and the Evangelical-Augsburg Parish in Pasym.

The main objectives of the project were:

- raising the awareness of Pasym's inhabitants about the historical value of this city's oldest Evangelical cemetery;

- preparing documentation of the historical Evangelical cemetery and the Rutkowski family's burial chapel located there;

- increasing the competence of the volunteers, in the field of cultural heritage documentation.

${ }^{8}$ Translated from German: "Resting place/of the Prussian royal expeditor/Samuel and Ewa née Biendara, spouses by the name of Rutkowski/funded/in the year of great suffering of 1856/by the surviving husband" (Pestka 2013: 4). 
The first activities under the project were the field workshops for volunteers, attended by 13 people, mostly undergraduate students in their senior year, postgraduate students, and doctoral students majoring in: history, art history, archeology, cultural and natural heritage. They took part in workshops on scanning, photogrammetry, photography, and preparation of record cards. During the field workshops, the participants - together with specialists who normally work at the Regional Digitization Workshop that operates at the "Światowid" Center for European Meetings - documented the historical Evangelical cemetery and the Rutkowski family's burial chapel. The prepared inventory cards, map, photographs, and 3D animations, made available at cyfrowewm.pl (Fig. 2), were also submitted to the Provincial Heritage Monuments Protection Office in Olsztyn, and to the City and Commune Hall in Pasym (Fig. 2). The activities under the project were primarily aimed at preserving and emphasizing the existing grave curbs and gravestones. The finding of funds, and the securing of a monument until the development design has been completed, are the responsibilities of the owner of a monument.

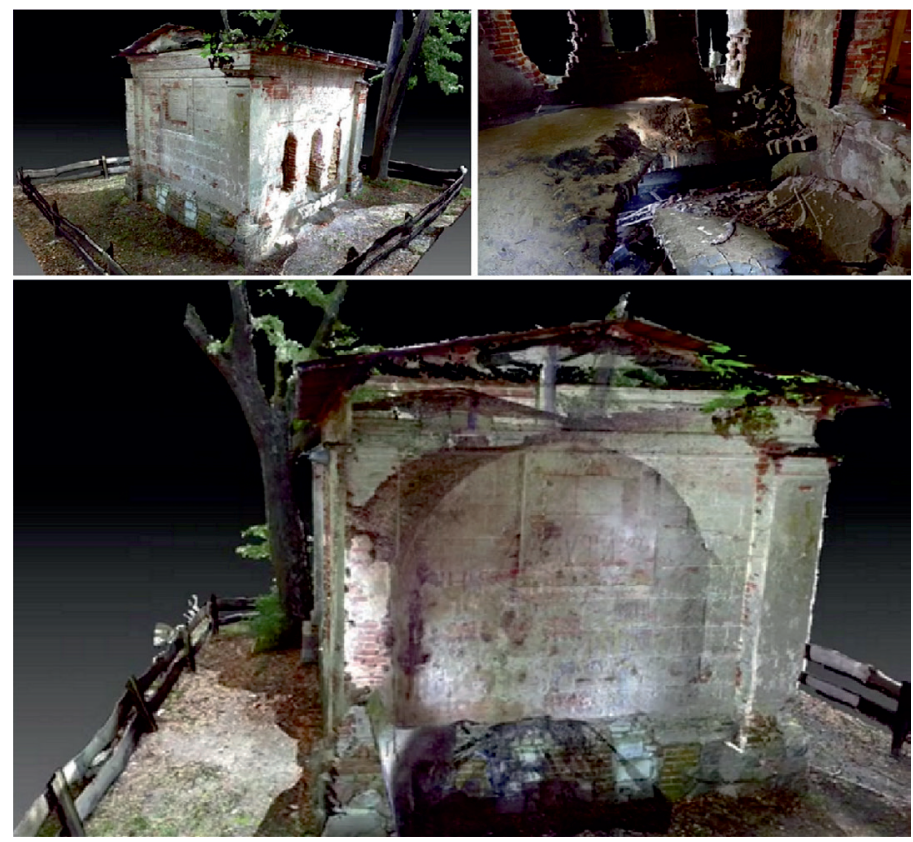

Fig. 2. 3D model of the Rutkowski family's burial chapel in Pasym, developed on the basis of a point cloud from ground-based laser scanning (author of the project: Paweł Kondraciuk, 2018

- Regional Digitization Workshop, Elbląg)

Source: the model is available at: http://www.cyfrowewm.pl/obiekt/549/ kaplica-grobowa-rodziny-rutkowskich-w-pasymiu [28.01.2019]. 
An important issue, emphasized also during the meetings with the inhabitants and students, was the heritage of these lands and the origin of the cemetery. After the Second World War, in the territory of the present-day Warmia and Masuria Province, a practically complete exchange of people happened. The cultural continuity of these areas was interrupted ( $c f$. Domagała 1992). The new inhabitants, leaving their homes, came to a land that was foreign to them (vide e.g. Bagaż doświadczeń $i$ wspomnień... 2018). Often, they even hated its former inhabitants and tried to erase their traces, filling in the created 'cultural gap' with their own cultural heritage ( $c f$. Knercer 2003). Cemeteries - as material traces of people who had previously lived in those areas - deprived of care, were subject to degradation. The gravestones located there were in many cases irretrievably lost, becoming a source of stone (information about the transformations of the Masurian cemeteries can be found, inter alia, in: Lewandowska 2013). The new inhabitants did not understand their importance as testimonies to the past of those lands, and had no respect for their former inhabitants, which made it even more difficult to build a regional identity. Gradually, local historians, conservators, local authorities, but also ordinary inhabitants began to pay attention to the historical necropolises (vide Jasiński 1993). This process is ongoing now. Successive generations know history, but it did not 'touch' them directly, so there are no negative emotions that determined the attitude of their grandparents or great-grandparents to sites such as old Evangelical cemeteries. Today, we look at them through the prism of monuments that testify to the rich local history that had been created by the people buried there (e.g. the three $19^{\text {th }}$ century mayors of Pasym). In order to show the inhabitants the richness of the local cultural heritage, as well as Pasym from a different perspective, somewhat 'from the outside', the volunteers were tasked with preparing short presentations for the residents. Making the inhabitants of Pasym aware of the value of this city's oldest necropolis, we tried to sensitize them to the importance of local cultural heritage. We created a positive emotional bond between the present residents of Pasym and the cultural heritage of their predecessors forced to emigrate in the wake of the war. We supported the restoration of the broken cultural continuity and respect for the material mementos of the prewar inhabitants. The current residents, accepting them as their own cultural heritage, will be able to build on its basis a sense of their regional identity.

Thanks to such a meeting and selection of topics, the volunteers had an opportunity to discuss the topics tackled during the workshops first with each other, and later also with the inhabitants of the city. An extremely valuable experience, for both the residents who came to the meeting and the volunteers, was the opportunity to talk together. Not only did the inhabitants learn something new about Pasym, but also the project participants heard some stories from the life of the local community, which they had not yet had an opportunity to learn. This meeting was also a needed and successful attempt at proving that researchers 
can go to the local community, meet it on neutral ground, and talk about their experiences and activities in a convention that is favorable to both sides of the dialog (similar activities, inter alia: Karpińska 2016: 36-41).

Implementation of all the activities planned under the project (workshops for children and youth, a location-based game, lectures) was supposed to increase the awareness of the inhabitants about the cultural heritage, the value of Pasym's monuments, and the local Evangelical cemetery. Several dozen residents of Pasym took part in the activities. Based on the questionnaires filled in during the events, it can be concluded that this goal was achieved to a large extent. The activities carried out during the implementation of the project entitled "Evidently important: documentation of the cemetery and the chapel in Pasym" show just how important interest coming from outside, beneficial activities, new ideas, and cultural heritage education are for such a small community.

\section{Participant's perspective}

Our goal was to document the current state of cultural and natural heritage of the cemetery using traditional (e.g. cemetery cards, photography) and new (e.g. photogrammetry, laser scanning, structured-light scanning) tools, methods, and techniques for monument documentation ${ }^{9}$ (Fig. 2,3). The use of a laser scanner allowed, among other things, to develop the 3D model of the Rutkowski family's burial chapel, based on which it is possible, inter alia, to observe and evaluate the structural elements of the building and the degree of their damage, thanks to the highly detailed measurements. What is more, the multidimensionality allows to examine the relation between the internal vaulting and the external roofing (vide Fig. 2 - the bottom illustration). This type of analysis lets us look at the sites of the $19^{\text {th }}$ century Evangelical heritage from a different perspective. Sites which, as a result of cultural and natural processes, assume the form a permanent ruin, are nowadays becoming (among others in archeology) the subject of research into the decomposition that takes place in the cultural landscape (vide e.g. Kobiałka 2014).

During the inventory-taking of the cemetery area, next to the original elements of the cemetery structure from the period of its use for burial purposes (fragments of gravestones, fences of burial fields, fragments of ceramic torches - Fig. 4), relics showing its later history were identified too (e.g. a contemporary coin, plenty of litter).

I think that such documentation can successfully capture the transient, ephemeral landscape of the cemetery. 'Ephemeral' because the composition of its landscape is strongly associated with the growth cycle and changes of the time periods (Fig. 2). In each period, especially in the historic ones, the cemetery had

${ }^{9} \mathrm{We}$ also participated in the workshops, during which we learned to apply the newest documentation techniques. 
a set of unique, elusive features of the ephemeral space (e.g. Brassley 1998). The individual photographs and visualizations that we made, preserve our knowledge as well as the perception of this landscape at a given point in time - it is also the so-called frozen palimpsest (Kijowska et al. 2011).
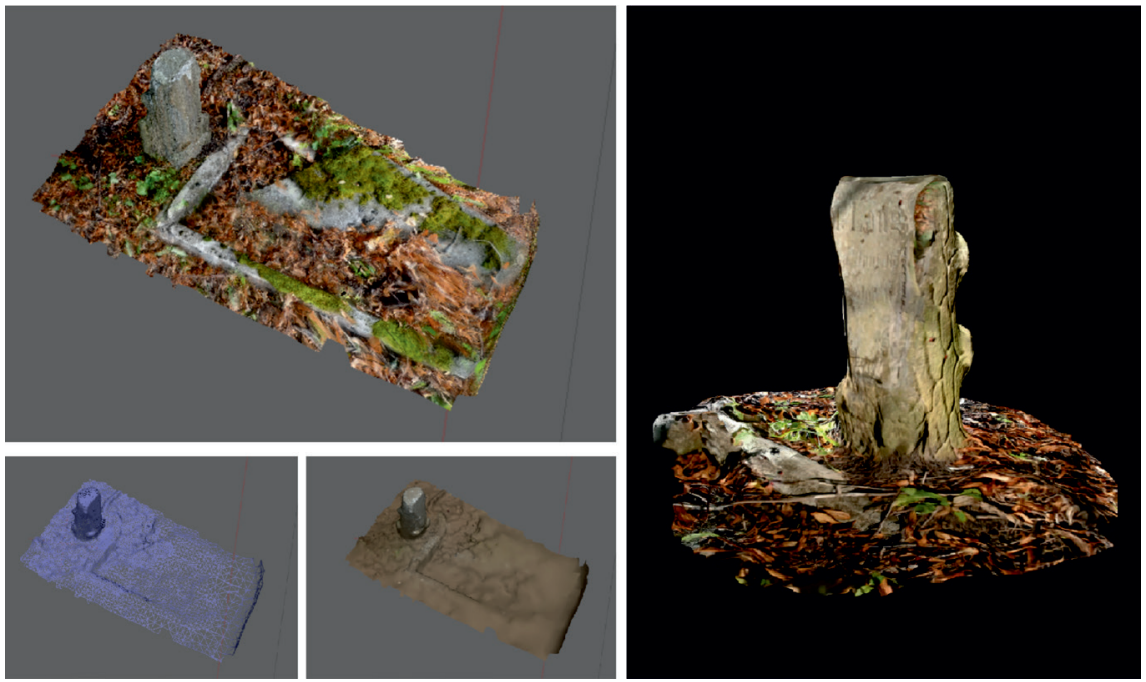

Fig. 3. 3D model of a gravestone in the old Evangelical cemetery in Pasym, developed on the basis of photographic documentation made during the inventory-taking works under the project entitled Evidently important: documentation of the cemetery and the chapel in Pasym

Source: elaborated by A. Majewska (2018).
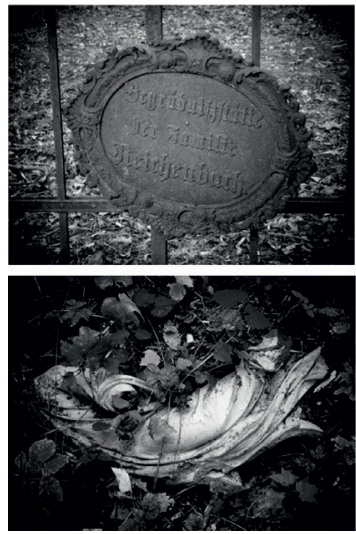
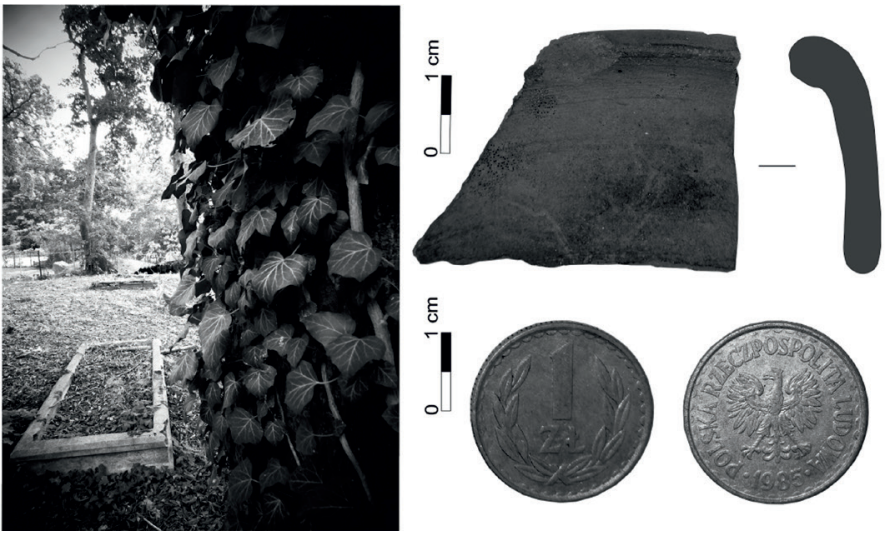

Fig. 4. Material carriers of information about the history of the burial space; Elements of the on-the-ground structure of the Evangelical cemetery in Pasym - a selection

Photo by A. Majewska (2018). 
It is an example of retrieval (remembrance) of space and its history, because of the fact that the cemetery is located within an inhabited town, it also has an Evangelical community - a certain cultural continuity has been maintained. The cemetery is in various ways and functions, and to a varying degree, present in the local social discourse, which can also be seen in its space in which there is abundant evidence for the presence of people. At the same time, this cemetery has become a natural-cultural space (Kobiałka 2018), a place where animals reside and are fed. At the end of the research, a meeting with residents was organized during which we not only presented the results, but which was also a complement to the process of remembrance of the space of the cemetery - its relying on recalling its history, and at the same time confronting what we know with social narratives, memories, local discourse.

\section{Evangelical cemetery in Wilki (a deserted village)}

\section{Project: Lost Villages of the Pisz, Forest}

\section{Organizer's perspective}

The plot of Ernst Wiechert's Masurian saga "The Jeromin children" takes place in the village of Sowiróg on Lake Nidzkie, one of those small villages in the Pisz Forest which the writer called 'lost' and compared to 'sunken graves' (cf. also: Bałtroczyk 1993; Konończuk 1993). This comparison turned out to be prophetic because, after the end of World War II, all that remained of the literary Jeromins' village were looted ruins and an abandoned cemetery. A similar fate befell many 'lost' villages in the Pisz Forest, in the area from the Pisa River to Lake Nidzkie, whose names remain only on old, sufficiently detailed maps.

The years and reasons for establishing these villages were various, but the two world wars led to the end of them all, making this their common denominator. The First World War caused huge material losses (which, paradoxically, led to the modernization of the countryside during its reconstruction, and improvement in the living conditions of its inhabitants), and the Second World War closed the history of East Prussia and interrupted the functioning of many villages, among others in the Pisz Forest. After the front line shifted in late January 1945, the area of today's Pisz County, like the whole Masuria, was almost completely depopulated. A time of looting and robberies came, committed by Russian soldiers, Polish militia, neighbors from beyond the former border, and newcomers from more distant parts of the country (vide e.g. Zaremba 2012: 275). First, Soviet soldiers looted everything they could. Later, the deserted villages fell victim to Polish looters. Furniture, household appliances and farming equipment were stolen, entire homesteads were disassembled, treating abandoned villages as storehouses of construction materials used to build new houses or for renovations. Gangs of looters sometimes set fire to wooden buildings in order to erase the traces or to 
distract the attention of inhabitants remaining in the village and make the criminal activities easier for themselves. In this way, villages disappeared from the Pisz Forest one by one. The only proof that they existed visible in the landscape are the foundations of houses and the abandoned cemeteries.

My interest in cemeteries as traces of the history and culture of Masuria recorded in the landscape, the reading of "The Jeromin children" by Wiechert, and the searching for the village of Sowiróg described there now completely depopulated, inspired me to elaborate an original project in 2008 entitled "Lost villages of the Pisz Forest" (Worobiec 2008). Its main assumptions are:

- discovering - what for more than half a century, hidden in the forest, has remained of the former villages, and what is slowly being absorbed by nature; recognizing and identifying those hidden and illegible places on site;

- making legible - tidying the cemeteries up, securing them against further destruction: fencing them in, setting up information boards etc.; cleaning, preserving, and reconstructing inscriptions on gravestones, inventory-taking of the status quo;

- restoring - the memory of the history of places and people living there, usually written down on gravestones of which there are fewer and fewer; preparing a book publication (currently in the editorial office), preparing a map (already published), marking out a tourist route and setting up boards with a short note about them in each village;

- educating - 'practical history lessons', encouraging the activity of local communities and popularizing the idea of volunteering (Fig. 5).

I presented the elaborated idea for the project in written form in May 2008 to the "Sadyba" partners from the "Borussia" Cultural Community of Olsztyn" In April 2009, a cooperation agreement was concluded between: The "Borussia" Foundation from Olsztyn, the National Center for Research and Documentation of Monuments in Warsaw (currently the National Heritage Institute), the Pisz Forest District Office, and the initiator, i.e. the "Sadyba" Association for the Protection of the Cultural Landscape of Masuria (from Kadzidłowo). Its aim was to organize a three-year series of summer workshops for volunteers from Poland, Russia, and Germany. According to the agreement, "Sadyba" presented the concept of the project and undertook to cooperate with regard to factual information, and to organize accommodation for project participants. "Borussia" conducted the recruitment of volunteers and co-financed the project. The NCRDM conducted the recruitment among Polish volunteers, co-financed the project, and took care of the factual information. The Pisz Forest District Office provided logistic assistance

${ }^{10}$ The project aroused the interest of Beata Samojłowicz (then the President of the Association) and Iwona Liżewska (acting as the head of the Regional Center for Research and Documentation of Monuments in Olsztyn) and, with the support of Pisz Forest District Manager Ryszard Grzywiński, a decision was made to carry it out. 
on site and co-financed promotional activities. The project was carried out ${ }^{11}$ for three consecutive summer seasons in the years 2009-2011, and, after a break of several years, has been continued since 2017 thanks to an agreement concluded between: "Sadyba", "Borussia", the "Stowarzyszenie Przyjaciół Starego Ogólniaka" association from Pisz, the "Stiftung Gerhart-Hauptmann-Haus" foundation from Düsseldorf, and the Pisz Forest District Office, in cooperation with the University of Warmia and Masuria in Olsztyn.

General cleaning works in cemeteries (removal of shrubs and trees, setting up overturned gravestones, fencing) are carried out by volunteers - students and graduates, during summer camps. Apart from working, project participants also take part in lectures on volunteering, the history and cultural landscape of Masuria, the history of lost villages, as well as in workshops on documentation of monuments. In addition, they have the opportunity to get to know interesting places connected with the history of the Pisz Forest (Wojnowo and Kadzidłowo) and admire the beauty of Masurian nature while kayaking down the Pisa River.

Cemeteries that have been tidied up require constant care. This is necessary especially in places where there used to grow dense bushes of the common snowberry - an invasive species that quickly reproduces by sprouting from its roots - they must be systematically removed. This is why, since 2009, high school students from Pisz have also been getting involved in the continuation of the volunteers' work ${ }^{12}$. In addition to helping during summer camps, successive classes of first- and second-year students also tidy up the cemetery in Wądołek every year (where the common snowberry grows back the fastest), thus becoming 'guardians of memory' ${ }^{13}$ and setting a good example to the local community.

To date, under five editions of the project, 10 cemeteries in the Pisz Forest have been tidied up and fenced - in the following localities (listed in chronological order): Sowiróg, Wądołek (2009), Przerośl, Szast (2010), Piskorzewo, Wolisko Wielkie (2011), Paski Małe and Paski Wielkie (2017), Wilki and Pogobie Przednie (2018) (vede the activities in Fig. 5). Successive stages of the project ended in setting up information boards (in Polish and German) about the abandoned villages in which the volunteers worked (11 boards were set up in 7 villages). The ideas and objectives of the project as well as its implementation and work of the volunteers aroused great interest of the media and became the subject of many

${ }^{11}$ As a result of a typographical error, the "Lost villages of the Pisz Forest" project functioned under the Polish name of Zaginione wioski Puszczy Piskiej (instead of Zagubione wioski...).

${ }^{12}$ Students from the Complex of General Education Schools, currently the High School in Pisz under the direction of history teacher Agnieszka Tuzinowska.

${ }^{13}$ This term was used as the title of the documentary about their work shot by TVP Olsztyn (Winda regionu: Strażnicy pamięci 2012). 

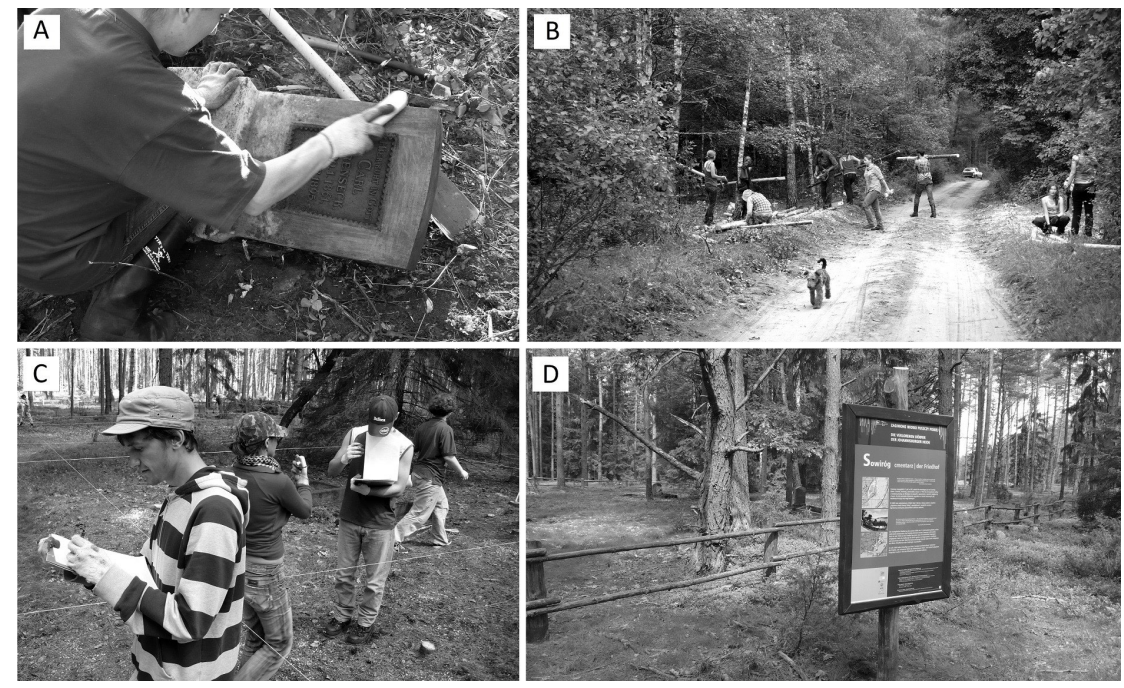

Fig. 5. Activities under the project entitled "Lost villages of the Pisz Forest": A - making legible - preserving (Wądołek - 2009), B - consolidating and securing - fencing (Przerośl - 2010), C - documenting - inventory-taking (Sowiróg - 2009),

$\mathrm{D}$ - restoring the memory and educating - information boards (Sowiróg - 2010)

Photo by K.A. Worobiec

articles in daily press and periodicals ${ }^{14}$, radio and television programs, including the "Wioska jak las" series of programs broadcast on Radio Olsztyn (Kulik 2013), and two documentary films made for TVP ${ }^{15}$. Issues related to the depopulated localities of the Pisz Forest (their relics, e.g. cemeteries) also became the subject of scientific elaborations (inter alia: Długozima et al. 20156; Kardach 2015; Majewska 2017, 2018; Żurkowska 2008; Żywiczyński 2017).

${ }^{14}$ Among others, a series of 25 articles published in "Gazeta Piska" from 7 March to 29 August 2014 - vide, inter alia, K.A. Worobiec 2014a,b,c as well as the numbers from: 7 August 2009, 13 August 2010, 19 August 2011. Articles were also published in: "Gazeta Wyborcza" (Olsztyn, 29 May 2009; 8 August 2009); "Tygodnik Piski" (2 August 2009; 13 August 2009; 5 August 2010; 18 June 2011; 20 June 2011; 16 August 2011; 7 November 2013); "Borussia. Kultura. Historia. Literatura” (2009/No. 46); "Johannisburger Heimatbrief" (2011); "Biuletyn Informacyjny Urzędu Miasta i Gminy Ruciane-Nida" (2011/ No 9; 2014/No. 1) Polska Agencja Prasowa (30 July 2009); “Gazeta Współczesna” (5 August 2009); "Przekrój” (6 August 2009); "Kontakt. Magazyn Nieuziemiony” (2015/No. 28).

${ }^{15}$ B. Hyży-Czołpińska, Zaginione wioski (12'08'), and Zagubione wioski Puszczy Piskiej (24'), TVP S.A.

${ }^{16}$ The elaboration contains the results of the largest (to date) research project concerning the Protestant cemeteries of Masuria. It was carried out by a research team from the Warsaw University of Life Sciences. The research conducted in the territory of the Pisz Forest District included 46 cemeteries. 


\section{Participant's perspective}

The second project is more connected with the reconstruction of the past than with its remembrance, because it does not take place with the participation of a still living social local discourse. These include activities that are undertaken under the project entitled "Lost Villages of the Pisz Forest". During this project, the so-called restoration of memory was facilitated by archival materials and the use of information obtained during cataloging, thanks to which - the history of the village and its image were (re)constructed.

The first step was to search for information about abandoned villages and cemeteries within their documentation in the city archives. Then, the project assumed inventory of the cemetery area of Wilki - one of deserted villages (including identification of its border), cataloging and pre-conservation of the tombstones. During the work carried out in the cemetery, movable historical objects were also identified and inventoried, constituting relics of the cemetery's structure (for example, a letter cut out of sheet metal, probably a fragment of a grave mark - Fig. 6) and even the former functioning of the village, like an iron fragment of a vessel (Fig. 6).
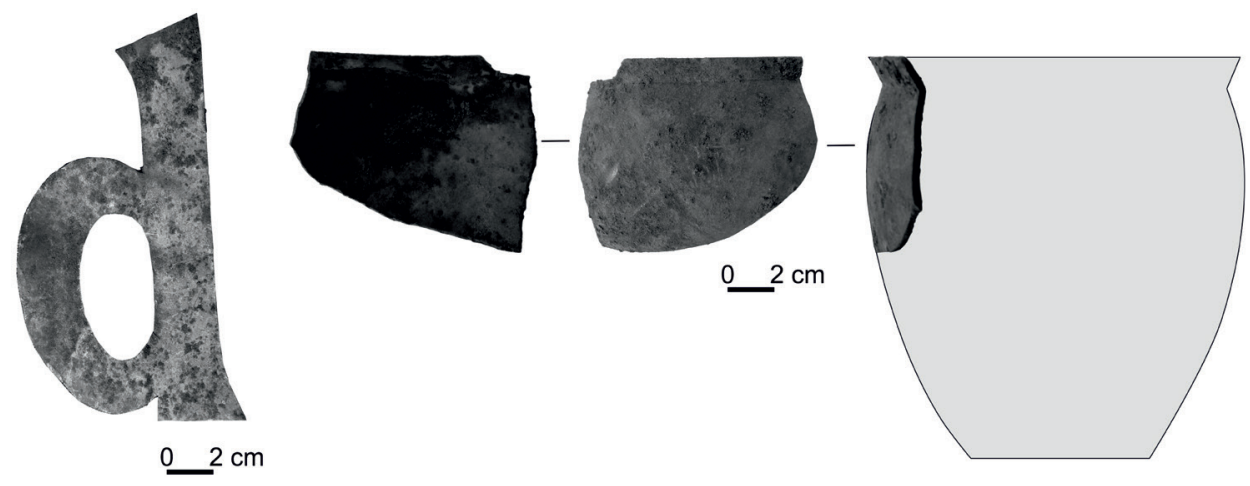

Fig. 6. Movable objects identified and documented in situ (Evangelical cemetery in the abandoned settlement of Wilki)

Source: photo and elaboration by A. Majewska (2018).

In the Evangelical cemetery in the village of Wilki, within several dozen years from the end of its functioning as an active burial place, there has been a significant succession of vegetation, which had not previously been an element of the cemetery planning scheme. This has significantly disrupted the legibility of the spatial layout of the on-the-ground part of the cemetery. Cleanup and conservation works made it possible to identify numerous grave markings, which had previously been imperceptible in the cemetery's landscape. A map of the cemetery planning scheme was elaborated, based on inventory data. Unexpectedly, 
a successful reconstruction was also performed on one of the cemetery carriers of information and memory of the site's history and the associated community of the depopulated village - a broken opaque-glass epitaph plate of one of the gravestones (Fig. 7).
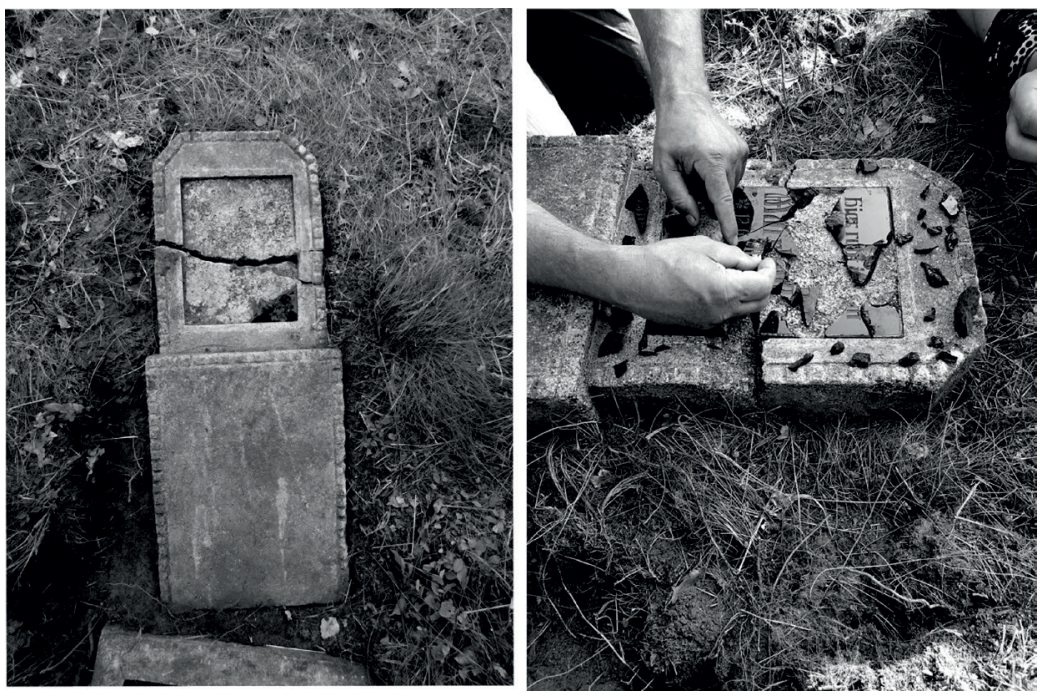

Fig. 7. Reconstruction of an opaque-glass grave plate in the Evangelical cemetery in the area of the depopulated settlement of Wilki in Piła County

Photo by A. Majewska (2018).

The activities undertaken in cemeteries in the abandoned villages under this project are also shaping historical memory to an extent greater than activities aimed only at the protection and preservation of the tangible cultural heritage. The boards set up in cemeteries or at the centers of depopulated villages provide information on the history of this deserted landscape, which has been silenced for many years.

\section{Conclusion}

The projects, which are the subject of this elaboration, have gone beyond the narrow disciplinary framework that has dominated in research works to date. Their interdisciplinary assumptions place them in the group of contemporary landscape studies focused on multifaceted analyses, going beyond traditional inventory-taking works. An integral part of the projects are social and educational activities aimed at popularizing knowledge of cultural heritage, methods for its protection and conservation, as well as increasing awareness of its value among local communities. The structures of the Evangelical cemeteries are carriers 
of the memory of the former cultural landscape of Masuria, and thanks to the activities taken under the presented projects, the history of those places is read and preserved for future generations. Their microhistorical perspective is also a tribute to locality in the so-called era of globalization.

The use of various (including the latest) methods and techniques of documentation, as well as the drawing on the approaches of various disciplines, make it possible to gain new knowledge of tangible cultural heritage sites and the communities which created and used them - sites that undergo continuous transformations, both natural and anthropogenic. This is of particular importance in activities concerning sites which today often operate in isolation from the original socio-cultural context, although they can be considered to be heritage related to recent past. In the landscape of Masuria, we can see numerous 'reflections' of socio-political transformations connected with the course and consequences of the Second World War. It is only after several decades that activities are initiated which constitute bridges between the material and non-material values of the past and present cultural landscape.

\section{References}

Bagaż doświadczeń i wspomnień. Relacje osadników polskich na Warmii I Mazurach po 1945 roku, P. Bojarski, E. Janowska (eds.), Olsztyn.

Bałtroczyk P., 1993, Konserwatywna utopia Ernsta Wiecherta w “Dzieciach Jeronimów”, "Borussia: Historia - Kultura - Literatura", 6: 84-91.

Bielawny K., 2006, Nekropolie w granicach parafii ewangelickich Nawiady, Piecki i Stara Ukta przed 1945 rokiem, "Znad Pisy”, 15: 162-211.

Bitowt R., 1999, Nekropolie Mragowa, "Mrągowskie Studia Humanistyczne”, 1: 103-113.

Brassley P., 1998, On the unrecognized significance of the ephemeral landscape, "Landscape Research", 23(2): 119-132.

Chlebowicz B., Strużyński J., 1995, Kaplica grobowa Rutkowskich, Karta Ewidencyjna Zabytków Architektury i Budownictwa nr 2336, PSOZ, Olsztyn.

Chłosta J., 2011, Działalność Społecznego Komitetu Ratowania Dawnych Cmentarzy na Warmii i Mazurach, "Komunikaty Mazursko-Warmińskie", 4(274): 715-734.

Dąbrowska-Budziło K., 2011, Genius loci jako potencjalne źródło inspiracji dla ksztattowania krajobrazu, "Prace Komisji Krajobrazu Kulturowego. Niematerialne wartości krajobrazów kulturowych", 15: 227-235.

Długozima A., Dymitryszyn I., Winiarska E., 2013, Tanatoturystyka jako nowa, potencjalna forma turystyki w lasach Mazur, wykorzystujaca zasób historycznych i zabytkowych cmentarzy ewangelickich, "Studia i Materiały CEPL w Rogowie", 15/37(4): 83-89.

Długozima A., Dymitryszyn I., Winiarska-Lisiecka E., 2015, Inwentaryzacja, analiza $i$ waloryzacja nieużytkowanych cmentarzy ewangelickich $w$ Nadleśnictwie Pisz. Wytyczne do rewaloryzacji i ochrony cmentarzy, Warszawa. 
Domagała B., 1992, Warmia i Mazury-dezintegracja i tożsamość po 1945 roku, "Borussia: Kultura - Literatura - Historia", 3-4: 54-64.

Jamiołkowska D., 1993, Dlaczego powinniśmy ratować stare cmentarze?, "Komunikaty Mazursko-Warmińskie", 2: 239-241.

Jasiński J., 1993, Dlaczego powinniśmy ratować stare cmentarze i groby na Warmii i Mazurach?, "Borussia: Kultura - Historia - Literatura", 6: 47-51.

Jasiński J., 2003, Olsztyńskie nekropolie, [in:] Achremczyk S., Ogrodziński W. (eds.), Olsztyn 1353-2003, Olsztyn: 600-613.

Kardach M., 2015, Verlorene Dörfer der Johannisburger Heide - eine Fallstudie zur kulturellen Landschaft als transgressiver Raum, [in:] Kopij-Weiß M., Zielińska M. (eds.), Transfer und Vergleich nach dem Cross-Cultural-Turn, Leipzig: Leipziger Universitätsverlag: 441-455.

Karpińska G.E., 2016, Diagnoza badawcza gminy - etnografia, [in:] Karpińska G.E., Majorek M. (eds.), Miejsca pamięci i zapomnienia. Interdyscyplinarne badania na Jurze Krakowsko-Częstochowskiej. Raport z badań, Tom 3: Gmina Olsztyn, Łódź: 21-49.

Kijowska J., Kijowski A., Rączkowski W., 2011, Krajobraz i polityka - wybrane aspekty wptywu decyzji politycznych na zmiany krajobrazu w Polsce, "Prace Komisji Krajobrazu Kulturowego. Niematerialne wartości krajobrazów kulturowych", 15: 103-115.

Knercer W., 2003, Ślady na ziemi-pasymskie cmentarze, "Rocznik Mazurski”, 7: 160-163.

Knercer W., 2006, Cmentarze południowych Mazur, [in:] Jasiński G., Kudrzycki Z., Misiuk A. (eds.), Powiat szczycieński: przeszłość - współczesność, Szczytno: 714-725.

Knercer W., 2008, Karta Cmentarza nr 959, Wojewódzki Urząd Ochrony Zabytków w Olsztynie.

Knercer W. Akincza M., Knercer-Grygo U., 2013, Pasym: cmentarz ewangelicko-augsburski przy ul. Tadeusza Kościuszki (m. Pasym, pow. Szczytno, woj. warmińsko-mazurskie). Inwentaryzacja dendrologiczna z gospodarka drzewostanem i analiza jego wartości. Inwentaryzacja historycznych kwater i nagrobków. Projekt zagospodarowania cmentarza, Olsztyn (documentation in the resources of Pasym Town Hall).

Kobiałka D., 2014, Let Heritage Die! The Ruins of Trams at Depot No. 5 in Wrocław, Poland, "Journal of Contemporary Archaeology", 1.2: 351-368.

Kobiałka D., 2018, Las, który łaczy kulturę i naturę - cmentarz jeńców wojennych w Czersku, woj. pomorskie, [in:] Karczewska M. (ed.), Cmentarze wojenne I wojny światowej po stuleciu. Stan badań i ochrony, Białystok: 121-139.

Konończuk E., 1993, Mazury Ernsta Wiecherta, "Borussia: Kultura - Historia - Literatura", 6: 80-84.

Kudrzycki Z., 2009, Cmentarze ewangelickie na terenie gminy Rozogi, "Rocznik Warmińsko-Mazurski Wojewódzkiego Urzędu Ochrony Zabytków”, 2: 5-18.

Kula M., 2002, Nośniki pamięci historycznej, Warszawa. 
Kulik A., 2013, Wioska jak las, serial radiowy (5 episodes), Radio Olsztyn, https://sadybamazury.wordpress.com/2013/03/03/wioska-jak-las-serial-dokumentalny-radia-olsztyn/ [27.01.2019].

Letkiewicz A., 2006, Z dziejów miasta i gminy Pasym, "Rocznik Mazurski”, 10: 16-20.

Lewandowska I., 2013, Trudne dziedzictwo ziemi. Warmia i Mazury 1945-1989, Olsztyn.

Lewandowska I., Romulewicz A., 2010, Historia kultury i dziedzictwo kulturowe Warmii i Mazur, Olsztyn.

Majewska A., 2016, Ukryte nekropolie - odczytywanie przestrzeni cmentarzy ewangelickich gminy Ełk, [in:] Z dziejów protestantyzmu i dobroczynności na Ziemiach Polskich w XIX i XX wieku w 150. rocznice urodzin Matki Ewy. Szkice monograficzne, BytomMiechowice: 24-43.

Majewska A., 2017, Relikty zanikłych jednostek osadniczych na pograniczu mazursko-mazowieckim. Interdyscyplinarny project badawczy, "Acta Universitatis Lodziensis. Folia Archaeologica", 32: 215-235.

Majewska A., 2018, Zanikte osadnictwo w granicach powiatu piskiego (typescript of the master's thesis), Uniwersytet Łódzki, Łódź.

Majgier J., 2010, Gleby cmentarne na przykładzie porzuconego cmentarza Rudówka Mała (Kraina Wielkich Jezior Mazurskich), III Geosympozjum Młodych Badaczy "Silesia 2010", "Prace WNoZ UŚ", 65: 119-128.

Majgier L., 2012, Analiza ekologiczna flory naczyniowej porzuconych cmentarzy Stara Rudówka i Rybical (Kraina Wielkich Jezior Mazurskich), “Acta Geographica Silesiana", 11: 41-48.

Majgier L., Rahmonov O., 2012, Selected Chemical Properties of Necrosols from the Abandoned Cemeteries Stabowo and Szymonka (Great Masurian Lake District), "Bulletin of Geography - Physical Geography Series", 5: 43-55.

Majgier L., Rahmonov O., 2013, Zróżnicowanie roślinności w obrębie porzuconych cmentarzy ewangelickich na terenie gminy Ryn, "Prace Komisji Krajobrazu Kulturowego PTG. Cmentarze i ogrody w krajobrazie. O sacrum, symbolice, kompozycji i przemijaniu", 22: 63-76.

Mazurowska A., 2009, Ślady przeszłości w imionach na epitafiach nagrobkowych cmentarza w Baniach Mazurskich, "Linguistica Copernicana", 2(2): 247-259.

Nekropolie Warmii i Mazur, 2016, W. Knercer, B. Wacławik (eds.), Olsztyn.

Orłowicz M., 1991, (reprint), Ilustrowany przewodnik po Mazurach Pruskich i Warmii, Olsztyn.

Pawłowska B., 2013, Inwentaryzacja i rekonstrukcja kaplicy grobowej rodziny Rutkowskich na cmentarzu ewangelickim w Pasymiu, (typescript), Olsztyn (documentation in the resources of Pasym Town Hall).

Pestka D., 2013, Grobowiec rodziny Rutkowskich na cmentarzu ewangelickim w Pasymiu. Dokumentacja badań konserwatorskich oraz program prac konserwatorskich, Olsztyn (documentation in the resources of Pasym Town Hall). 
Ploszaj-Witkowska B., Leoniak W., 2010, Analiza drzewostanu cmentarza ewangelicko-augsburskiego w Mrągowie, "Zeszyty Problemowe Postępów Nauk Rolniczych”, 551: 255-262.

Seaton A.V., 1996, From Thanatopsis to Thanatourism. Guided by the Dark, "International Journal of Heritage Studies", 2(4): 234-244.

Surminski A., 2008, Wieś w Prusach Wschodnich. Jäglack-Jokehnen-Polninken-Jegławki, Neulengbach.

Tanaś S., 2006, Tanatoturystyka - kontrowersyjne oblicze turystyki kulturowej, "Peregrinus Cracoviensis", 17: 85-100.

Winda regionu: Strażnicy pamięci, 2012, TVP Olsztyn, emission: 1.06.2012, http://olsztyn.tvp.pl/7627673/straznicy-pamieci [10.06.2012].

Worobiec K.A., 2008, Zagubione wsie Puszczy Piskiej - idea i założenia projektu, (typescript).

Worobiec K.A., 2014a, Zagubione wioski Puszczy Piskiej, cz. 5: Wielgilass i Pogobie Przednie, "Gazeta Piska", 4-10.04.2014: 10.

Worobiec K.A., 2014b, Zagubione wioski Puszczy Piskiej, cz. 8: Wądołek, "Gazeta Piska", 25.04.-1.05.2014: 10.

Worobiec K.A., 2014c, Zagubione wioski Puszczy Piskiej, cz. 12: Paski Duże i Małe, "Gazeta Piska", 23.05.2014: 10.

Zaremba M., 2012, Wielka trwoga, Polska 1944-1947. Ludowa reakcja na kryzys, Kraków.

Żurkowska T., 1999, Śródleśne cmentarze mazurskie, “Aura”, 10: 24-25.

Żurkowska T., 2000, Roślinność mazurskich cmentarzy - symbolika i wierzenia ludowe, “Znad Pisy", 9: 158-166.

Żurkowska T., 2008, Mazurskie cmentarze. Symbole w krajobrazie, Olsztyn.

Żywiczyński A., 2017, Relikty dawnej sieci osadniczej na terenach leśnych Puszczy Piskiej w Nadleśnictwie Pisz. Identyfikacja, możliwości poznawcze i metody eksponowania, [in:] Wysocki J. (ed.), Konserwacja zapobiegawcza środowiska. Dziedzictwo kulturowe w lasach, "Archaeologica Hereditas”, 4: 37-47, Warszawa-Zielona Góra.

\section{Internet source}

http://www.cyfrowewm.pl/obiekt/549/kaplica-grobowa-rodziny-rutkowskich-w-pasymiu [28.01.2019].

\section{Lokalność w erze globalizacji. Nosiciele pamięci historycznych krajobrazów - badania ewangelickich cmentarzy mazurskich}

Zarys treści: Głównym celem artykułu było przedstawienie współczesnych narracji (dyskursu społecznego i naukowego) na temat mazurskich cmentarzy ewangelickich. Temat zrealizowano w oparciu o przykłady działań dokonywanych w ramach dwóch projektów, których głównym założeniem jest przywrócenie pamięci o dziedzictwie kulturowym oraz objęcie go ochroną. Opracowanie dotyczy wybranych zagadnień z zakresu funkcjonowania materialnego dziedzictwa kulturowego na Mazurach (w szczególności 
w Pasymiu oraz jednej z opuszczonych wsi). W artykule omówiono jak wciąż na nowo interpretować można przestrzenie cmentarzy protestanckich, zwłaszcza w świetle wyników prowadzonych prac dokumentacyjnych.

Slowa kluczowe: dziedzictwo kulturowe, historia, dokumentacja, interdyscyplinarne projekty badawcze, protestantyzm, Prusy Wschodnie, lokalne społeczności.

Anna Majewska

University of Lodz

Faculty of Geographical Sciences

Department of Political and Historical Geography and Regional Studies

e-mail: anna.majewska@op.pl

Krzysztof A. Worobiec

The "Sadyba" Association for the Protection of the Cultural Landscape of Masuria, Kadzidłowo

e-mail: sadyba.mazury@gmail.com

Edyta Bugowska

The "Światowid" Center for European Meetings in Elbląg

e-mail: edyta.bugowska@swiatowid.elblag.pl 